\title{
Strategi Menghidupkan Motivasi Belajar Anak Usia Dini Selama Pandemi COVID-19 melalui Publikasi
}

\author{
Azizah Nurul Fadlilah $\bowtie$ \\ Pendidikan Islam Anak Usia Dini, Universitas Islam Sunan Kalijaga Yogyakarta \\ DOI: $\underline{10.31004 / o b s e s i . v 5 i 1.548}$
}

\begin{abstract}
Abstrak
Penelitian ini bertujuan untuk meneliti strategi guru Kelompok Bermain (KB) TK Al-Huda Kota Malang dalam menghidupkan motivasi belajar siswa demi menjaga keberlangsungan pendidikan dalam kebijakan Study From Home (SFH) pada masa pandemi COVID-19. Peneliti menggunakan jenis pendekatan penelitian kualitatif deskriptif dengan subjek penelitian yaitu guru kelas serta siswa Kelompok Bermain (KB) di TK Al-Huda Kota Malang. Teknik pengumpulan data yang digunakan adalah wawancara mendalam serta dokumentasi. Hasil penelitian menunjukkan bahwa bentuk strategi guru untuk menghidupkan motivasi belajar siswa dalam kebijakan SFH di tengah wabah COVID-19 adalah dengan publikasi hasil kerja tugas siswa yang terbukti dapat menghidupkan motivasi belajar siswa. Hambatan yang ditemui guru yaitu berkenaan dengan aspek orang tua peserta didik, sarana pembelajaran, dan kreativitas guru. Manfaatnya berupa tumbuhnya motivasi belajar siswa, melatih kedisiplinan siswa, serta membantu meningkatkan kedekatan antara orangtua dan anak.
\end{abstract}

Kata Kunci: motivasi belajar; anak usia dini; covid-19.

\begin{abstract}
This research aims to examine the strategy of the Play Group (PG) teacher in TK Al-Huda Malang for reviving learning motivation of students in order to maintain the sustainability of education in the policy of Study From Home (SFH) during the COVID-19 pandemic. Researcher uses a type of descriptive qualitative research approach with the research subject of class teacher and Play Group (PG) student at TK Al-Huda Malang city. The data collection techniques used are depth interviews and documentation. The results showed that the form of the teacher's strategy to animate the motivation for student learning in the SFH policy amid the COVID-19 outbreak was by the publication of the work of student's working assignments which proved to revive a student's motivation for learning. The barriers that teacher deal with are aspects about student's parents, learning facilities, and teacher's creativity. The benefits are growing of the student's motivation for learning, coaching students discipline, and helping to improve the closeness between parents and children.
\end{abstract}

Keywords: learning motivation; early childhood; covid-19.

Copyright (c) 2020 Azizah Nurul Fadlilah

$\triangle$ Corresponding author :

Email Address : azizahfadhilah123@gmail.com (Kediri, Jawa Timur, Indonesia)

Received 23 May 2020, Accepted 10 June 2020, Published 26 June 2020 


\section{PENDAHULUAN}

Sejak akhir tahun 2019 dunia mulai digemparkan oleh adanya virus baru yang dikenal dengan sebutan Corona Virus Disease 2019 (COVID-19). Wabah penyakit tersebut menyebabkan kekhawatiran yang cukup tinggi, sebab belum ditemukan vaksinnya. Virus yang berasal dari Negara China tersebut kemudian menyebar ke berbagai negara di dunia, termasuk Indonesia. Pada sekitar awal bulan Maret, virus ini mulai ditemukan di Indonesia. Dilansir dari laman halodoc.com pada Hari Senin Tanggal 2 Maret 2020 Presiden Jokowi membuat suatu pengumuman bahwa di Indonesia telah ditemukan dua pasien positif COVID-19. Sejak saat itu kasus wabah COVID-19 ini terus meningkat dan menyebar ke berbagai wilayah di Indonesia. Adanya wabah penyakit COVID-19 yang menyerang Indonesia ini memberikan dampak di berbagai sektor, mulai dari kesehatan, ekonomi, hingga pendidikan (Ibrahim, 2020). Hingga pada sekitar awal Bulan April pemerintah mengeluarkan kebijakan yang tertuang dalam Peraturan Menteri Kesehatan Republik Indonesia Nomor 9 Tahun 2020 tentang Pedoman Pembatasan Sosial Berskala Besar (PSBB) dalam Rangka Percepatan Penanganan Corona Virus Disease 2019, yang memberikan pembatasan dalam kegiatan keagamaan, sekolah, tempat kerja, tempat atau fasilitas umum, kegiatan sosial dan budaya, moda transportasi, serta kegiatan lainnya yang berkaitan dengan aspek pertahanan dan keamanan dengan beberapa persyaratan yang harus dipenuhi oleh wilayah-wilayah yang mengajukan PSBB.

Bentuk pelaksanaan PSBB dalam ranah pendidikan sesuai Permenkes RI No. 9 Tahun 2020 adalah dengan adanya peliburan sekolah yang mengganti proses belajar mengajar di sekolah dengan dilaksanakan di rumah menggunakan media yang paling efektif. Pelaksanaan kebijakan tersebut dikenal oleh masyarakat umum dengan sebutan Study From Home (SFH), dimana kegiatan pembelajaran dilakukan dengan sistem jarak jauh. Adanya kebijakan SFH tersebut memberikan tantangan baru bagi seluruh lembaga pendidikan. Tantangan tersebut sebab lembaga-lembaga belum pernah memiliki pengalaman menghadapi keadaan semacam ini sebelumnya. Kegiatan pembelajaran yang biasanya dilaksanakan di sekolah dengan adanya kegiatan belajar tatap muka langsung antara pengajar dengan peserta didik, namun kini harus dilakukan secara jarak jauh melalui sistem jarak jauh. Dalam pelaksanaan SFH di tengah wabah COVID-19 ini tentu menuntut adanya kerjasama baik antara seluruh stakeholders yang terdiri dari pemerintah, orangtua, guru, dan sekolah (Syah, 2020:399-400). Pada awal dikeluarkannya kebijakan SFH ini belum ada panduan jelas dan rinci bagaimana setiap lembaga pendidikan melaksanakan kegiatan pembelajaran dengan sistem SFH ini. Dalam kebijakan PSBB pun hanya disebutkan bahwa kegiatan belajar mengajar di sekolah diganti dengan kegiatan belajar mengajar di rumah dengan media yang paling efektif. Banyak guru yang kebingungan menentukan bagaimana cara belajar yang tepat dengan sistem tersebut, agar meski dilakukan di rumah, proses pembelajaran tetap berjalan dengan baik.

Membahas mengenai pendidikan, menurut Undang-Undang Republik Indonesia Nomor 20 Tahun 2003 tentang Sistem Pendidikan Nasional, jalur pendidikan yang ada di Indonesia terdiri dari pendidikan formal, nonformal, dan informal. Sedangkan Pendidikan Anak Usia Dini (PAUD) termasuk kedalam pendidikan nonformal. Meskipun bukan termasuk pendidikan formal, namun dalam Peraturan Menteri Pendidikan Dan Kebudayaan Republik Indonesia Nomor 146 Tahun 2014 tentang Kurikulum 2013 Pendidikan Anak Usia Dini (PAUD) bahwa PAUD merupakan jenjang pendidikan yang dianggap paling fundamental, sebab perkembangan anak pada masa berikutnya akan sangat ditentukan oleh berbagai macam stimulasi bermakna yang diberikan sejak usia dini, dimana masa usia dini merupakan masa yang paling tepat untuk pemberian stimulasi-stimulasi tersebut agar anak dapat berkembang secara optimal. Sehingga dapat dipahami bahwa PAUD sangatlah penting bagi anak usia dini untuk menunjang kehidupannya selanjutnya. Kemudian, dalam Peraturan Menteri Pendidikan Dan Kebudayaan Republik Indonesia (RI) Nomor 137 Tahun 2014 tentang Standar Nasional Pendidikan Anak Usia Dini, bahwa PAUD terdiri dari 
lembaga pendidikan berupa Taman Kanak-kanak (TK), atau Raudatul Athfal (RA), atau Bustanul Athfal (BA), Kelompok Bermain (KB), Taman Penitipan Anak (TPA), serta Satuan PAUD Sejenis (SPS).

Tantangan dalam pelaksanaan SFH yang disebutkan sebelumnya tentu juga dihadapi oleh lembaga PAUD. Disamping mengalami kebingungan dalam beradaptasi dengan sistem pembelajaran SFH tersebut, para guru juga dituntut untuk menunjukkan bahwa kegiatan pembelajaran tetap terlaksana, baik kepada pengawas sekolah, para walimurid, peserta didik, maupun masyarakat sekitar pada umumnya. Sehingga, para guru tetap nampak menjalankan tugasnya dengan baik sebagai pendidik meski dalam kondisi di tengah wabah seperti ini. Hal tersebut sebagai suatu bentuk tanggungjawab atas tugas yang diberikan kepada guru selaku tenaga pendidik dan pengajar. Dalam kondisi seperti ini, kegiatan belajar mengajar harus tetap berjalan. Pemenuhan hak setiap anak bangsa atas pendidikan harus tetap terpenuhi, apapun yang terjadi. Oleh sebab itulah, guru sebagai penggerak roda pendidikan harus tetap menjalankan tugasnya dengan baik.

Tantangan lain yang dihadapi oleh lembaga PAUD dalam menerapkan kebijakan SFH adalah menghadapai karakteristik anak usia dini yang baru mulai memasuki dunia sekolah. Anak baru belajar bagaimana bersekolah dan masih beradaptasi dengan kehidupan sekolah. Selain itu, ada pula karakteristik anak usia dini yang masih sering moody, apalagi dalam hal belajar. Terkadang anak semangat bersekolah, kadang juga malas. Dapat dilihat bahwa motivasi belajar anak usia dini masih rendah dan masih membutuhkan bimbingan dan dorongan dari orang yang lebih tua, entah guru atau orangtua sebagai motivator atau penggeraknya. Oleh sebab itulah hal tersebut menjadi tantangan sendiri dalam hal motivasi belajar, apalagi melihat dalam kondisi penerapan kebijakan SFH yang kegiatan belajarnya dilakukan di rumah. Tanpa guru yang mendampingi serta teman-teman kelas yang biasanya menjadi teman belajar, tentu anak akan berkurang motivasi dan semangat belajarnya.

Contoh kegiatan pembelajaran berbasis jarak jauh di tingkat pendidikan tinggi, sebagaimana hasil penelitian yang dilakukan oleh Jamaluddin, dkk. (2020:1-10) bahwa hampir seluruh mahasiswa melakukan pembelajaran dengan sistem daring melalui beberapa jenis media pembelajaran online yang dilakukan sesuai jadwal perkuliahan yang telah ditetapkan oleh pihak fakultas, dan sebagian menyatakan bahwa pembelajaran dengan sistem daring ini dapat membantu mempermudah proses pembelajaran dalam kondisi tertentu. Kemudian ditambahkan oleh hasil penelitian Firman \& Rahayu (2020:81-89) yang menyatakan bahwa mahasiswa telah memiliki fasilitas-fasilitas dasar yang dibutuhkan untuk pelaksanaan pembelajaran dengan sistem online, model pembelajaran ini bersifat fleksibel dalam pelaksanaannya dan dapat mendorong munculnya kemandirian belajar dan motivasi para mahasiswa untuk lebih aktif dalam belajar, dan metode ini digunakan untuk menerapkan perilaku social distancing guna meminimalisir adanya keramaian mahasiswa sehingga dapat mengurangi potensi penyebaran wabah COVID-19 di lingkungan kampus. Jika dilihat dari pemaparan tersebut, dapat dilihat bahwa perubahan sistem pembelajaran di jenjang pendidikan tinggi tidak begitu menyulitkan. Meski ditemukan beberapa hambatan, namun dapat dilihat bahwa jalannya SFH dengan sistem daring tersebut berjalan cukup baik dan lancar. Lalu bagaimanakah kondisi di lembaga PAUD?

Adanya perubahan proses pembelajaran di tengah pandemi ini tentu menjadi suatu tantangan tersendiri bagi seluruh lembaga pendidikan. Damanik (2019:46-52) mengungkapkan dalam hasil penelitiannya yang dilakukan di sebuah sekolah tinggi swasta, bahwa lingkungan belajar memiliki pengaruh yang signifikan terhadap motivasi belajar. Lalu bagaimana jika lingkungan belajar berubah? Lingkungan belajar yang tadinya berada di sekolah bersama guru dan teman-teman kelas, sekarang berubah hanya di rumah didampingi oleh orangtua. Tentu akan membutuhkan adaptasi serta menimbulkan dampak bagi peserta didik. Lingkungan belajar harus diciptakan sepositif mungkin setara dengan lingkungan sekolah, agar motivasi belajar siswa dapat tumbuh. Bila lingkungan sekolah berkualitas tercipta serta motivasi belajar siswa tinggi, maka akan dapat meningkatkan hasil 
belajar peserta didik (Hasanah, 2015). Selain itu, motivasi belajar baik intrinsik maupun ekstrinsik harus dimiliki siswa karena memiliki kedudukan yang sangat penting agar tujuan pembelajaran yang telah ditetapkan dapat tercapai, serta agar adanya motivasi tersebut dapat memberikan semangat kepada siswa sehingga ia dapat mengetahui arah belajarnya (Emda, 2018:172-182). Dari pemaparan tersebut dapat dilihat betapa pentingnya motivasi belajar dalam suatu proses pembelajaran. Adanya motivasi belajar harus diupayakan ada dalam diri siswa, dan bila ada hambatan diusahakan pula untuk diminimalisir. Sehingga hasil yang ingin dicapai sebagai hasil dari pembelajaran dapat diperoleh secara maksimal.

Dalam beberapa penelitian terdahulu, ada beberapa bentuk metode yang digunakan sebagai upaya untuk menumbuhkan motivasi belajar siswa. Misal dalam penelitian yang dilakukan oleh Suryani (2015) yang menunjukkan bahwa metode Inquiry Discovery tepat digunakan untuk meningkatkan pemahaman dan motivasi belajar siswa jenjang Sekolah Dasar (SD) dalam belajar mata pelajaran IPA, sebab metode ini melibatkan siswa dengan aktif baik secara penglihatan, pendengaran, pikiran, psikomotor, dan keseriusan dan proses pembelajaran. Kemudian dalam penelitian Siregar (2015:127-140) di sebuah Sekolah Menengah Pertama (SMP) Negeri di Batangkuis, disebutkan bahwa metode tutor sebaya dapat digunakan untuk meningkatkan motivasi belajar siswa. Ada pula metode lain yang dapat digunakan untuk menumbuhkan motivasi belajar peserta didik, berdasarkan hasil penelitian Fathurrahman (2020) yang menunjukkan bahwa metode Role Playing dapat pula digunakan guru untuk menumbuhkan motivasi belajar siswa, yang mana dalam metode ini ada hubungan interaktif antara guru dan peserta didik maupun antar peserta didik dengan diskusi dan peragaan, sehingga peserta didik dapat mengembangkan perasaan, nilai, sikap, dan berbagai strategi dalam memecahkan masalah. Selanjutnya, Aulina (2018:1-12) dalam hasil penelitiannya yang dilakukan pada sebuah Taman Kanak-Kanak di Tanggulangin menyebutkan bahwa untuk meningkatkan motivasi belajar siswa dapat menggunakan metode Whole Barin Teaching yang mengharuskan guru untuk berusaha menarik perhatian siswa agar lebih fokus pada materi pembelajaran yang disampaikan oleh guru.

Beberapa bentuk metode yang dipaparkan di atas terbukti dapat berhasil digunakan guru untuk menumbuhkan atau meningkatkan motivasi belajar siswa, namun belum tentu dapat berhasil jika diterapkan pada kondisi saat ini. Adanya kebijakan SFH di tengah wabah COVID-19 ini yang mengaharuskan pembelajaran dilaksanakan di rumah, bukan di sekolah bersama guru dan teman-teman kelas. Sedangkan beberapa metode di atas dalam pelaksanaannya mengharuskan adanya interaksi antara guru dengan peserta didik, maupun antar sesama peserta didik. Perbedaan kondisi tersebut tentu akan membutuhkan penangan dengan metode yang berbeda pula. Oleh sebab itulah beberapa metode di atas akan sulit diaplikasikan oleh lembaga pendidikan di tengah kondisi seperti ini. Sehingga, harus dicari metode lain yang terbukti dapat berhasil menghidupkan motivasi maupun semangat belajar peserta didik, agar proses pembelajaran dapat berjalan dengan lancar.

Tujuan dari penelitian ini adalah memberikan gambaran strategi yang dapat dilakukan dalam upaya menumbuhkan motivasi belajar para peserta didik usia dini, khususnya peserta didik pada jenjang KB. Kemudian dipaparkan pula tentang hambatan yang dihadapi dalam penerapan strategi tersebut, serta manfaatnya. Diharapkan hasil penelitian ini juga dapat menjadi inspirasi bagi para pengajar di berbagai jenjang pendidikan, mulai dari jenjang PAUD, sekolah dasar, menengah hingga tinggi, yang mungkin bisa dikembangkan lagi menurut kondisi serta situasi setiap tingkat jenjang pendidikan. Dengan begitu, hambatan dalam pelaksanaan sistem pembelajaran SFH sebagai dampak COVID-19, terkait motivasi belajar peserta didik dapat teratasi dengan baik.

\section{METODOLOGI}

Pendekatan yang digunakan dalam penelitian ini adalah pendekatan kualitatif dengan jenis penelitian deskriptif. Peneliti menggunakan jenis pendekatan penelitian kualitatif deskriptif dikarenakan peneliti bertujuan untuk mendapatkan pengetahuan baru 
serta gambarannya terkait dengan strategi apa yang digunakan guru kelas Kelompok Bermain (KB) TK Al-Huda untuk menghidupkan motivasi belajar para peserta didik yang harus menghadapi kebijakan Study From Home (SFH) akibat bencana wabah COVID-19 yang menyerang Indonesia. Penelitian ini dilaksanakan terhadap TK Al-Huda yang beralamat di Masjid Al-Huda, Jalan Raya Kendalsari, Tulusrejo, Kecamatan Lowokwaru, Kota Malang. Peneliti melaksanakan penelitian ini mulai dari tanggal 16 Maret 2020 dimana kebijakan SFH mulai diterapkan di TK Al-Huda, hingga tanggal 20 Mei 2020. Berikut tahapan penelitian yang dilakukan oleh peneliti.

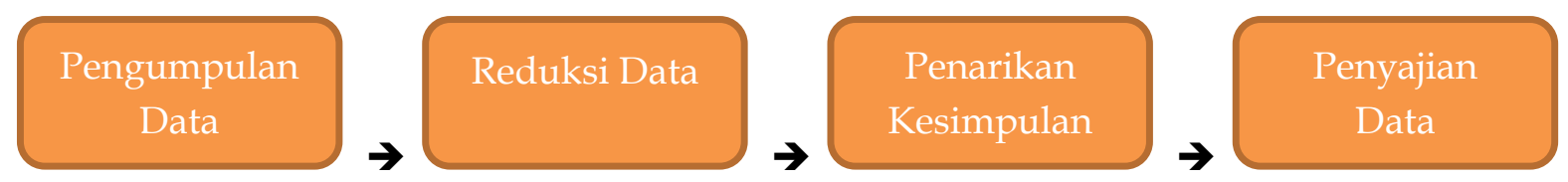

\section{Gambar1. Tahapan Penelitian}

Subjek penelitian dalam penelitian ini adalah guru kelas serta murid Kelompok KB di TK Al-Huda Kota Malang. Sedangkan peneliti bertindak sebagai penganalisa dan pengamat data yang kemudian juga sekaligus melaporkan hasil dari penelitian yang telah dilakukan. Teknik pengumpulan data yang digunakan dalam penelitian ini adalah dengan menggunakan metode wawancara mendalam serta dokumentasi. Dengan kondisi di tengah wabah COVID-19 ini, wawancara dilakukan melalui media telepon seluler dengan guru kelas KB TK Al-Huda untuk mengumpulkan informasi yang dibutuhkan oleh peneliti. Metode dokumentasi yang dipakai oleh peneliti yaitu mengamati beberapa postingan status whatsapp dan instagram guru yang memposting hasil kerja tugas para peserta didik KB TK Al-Huda beserta caption-nya.

\section{HASIL DAN PEMBAHASAN}

Adanya kebijakan Study From Home (SFH) akibat bencana wabah COVID-19 yang menyerang Indonesia menyebabkan berubahnya sistem pembelajaran yang diterapkan pada setiap lembaga pendidikan. Sistem pembelajaran yang biasanya dilaksanakan dengan tatap muka secara langsung di sekolah, namun sekarang harus dilaksanakan dengan sistem jarak jauh. Dari segi metode hingga sarana pembelajaran tentu mengalami perubahan demi menyesuaikan kondisi SFH dengan segala keterbatasan yang ada, yang berjalan tidak seperti proses pembelajaran biasanya. Perubahan tersebut terjadi mulai dari jenjang pendidikan anak usia dini, dasar, menengah, hingga tinggi. Lalu, bagaimanakah perubahan tersebut dalam lembaga PAUD?

Berdasarkan keterangan dari guru kelas, biasanya para peserta didik KB TK Al-Huda mengikuti kegiatan pembelajaran di sekolah bersama guru kelas seminggu sebanyak tiga kali, yaitu hari Selasa, Rabu, dan Jumat. Setelah adanya kebijakan SFH, sistem pembelajaran diubah menjadi pemberian tugas yang tetap disesuaikan dengan jadwal belajar seperti biasanya. Tugas yang diberikan sebanyak tiga tugas yang diberikan setiap seminggu sekali di awal pekan. Kemudian, setiap peserta didik mengirim hasil pengerjaan tugasnya sesuai jadwal belajar di sekolah biasanya yaitu pada setiap hari Selasa, Rabu, dan Jumat. Tugas yang diberikan pada awal pekan, biasanya wali murid ke sekolah untuk mengambil bahan tugas yang disediakan oleh sekolah, juga untuk mendapatkan penjelasan langsung dari guru berkenaan dengan cara mengerjakan tugas yang diberikan untuk meminimalisir kesalahpahaman pengerjaan tugas. Bentuk penugasan yang diberikan guru diolah dengan variasi yang beragam dalam setiap minggunya agar anak tidak merasa jenuh. Tugas dapat berupa pengerjaan buku majalah, membuat karya, membuat video yang menampilkan anak menyanyi, atau bentuk tugas lainnya. 
Pemaparan tersebut di atas sebagai sampel cukup menggambarkan bagaimana perubahan sistem pembelajaran yang ada di lembaga PAUD, khususnya KB. Adanya perubahan tersebut tentu mempengaruhi motivasi belajar peserta didik. Padahal, motivasi belajar sangatlah penting bagi siswa dalam suatu proses pembelajaran. Melihat betapa pentingnya motivasi belajar siswa dengan dihadapkan perubahan sistem pembelajaran dalam kebijakan SFH di tengah wabah COVID-19 ini, maka guru perlu mencari strategistrategi sebagai upaya untuk menghidupkan motivasi belajar peserta didik. Upaya tersebut tentunya harus efektif dan sesuai bila diterapkan pada jenjang PAUD. Sehingga adanya hambatan perihal motivasi belajar tersebut dapat teratasi dengan solusi yang tepat.

\section{Bentuk Strategi Guru Meningkatkan Motivasi Belajar Siswa Kelompok Bermain TK Al- Huda dalam Penerapan Kebijakan SFH}

Berdasarkan hasil wawancara yang telah dilakukan peneliti dengan guru kelas Kelompok Bermain (KB) TK Al-Huda, bentuk upaya yang dilakukan agar motivasi belajar para peserta dapat hidup selama belajar di rumah adalah dengan metode publikasi hasil belajar peserta didik. Sebagaimana dipaparkan sebelumnya bahwa dalam pelaksanaan SFH sebagai dampak adanya wabah COVID-19 ini, sistem pembelajaran di KB TK Al-Huda yang biasanya dilaksanakan di sekolah kini berubah dengan pemberian tugas yang dikerjakan di rumah. Tiga tugas yang dibagikan setiap awal pekan, dikumpulkan kepada guru kelas sesuai jadwal masuk sekolah biasanya yaitu setiap hari Selasa, Rabu, dan Jumat. Setiap tugas yang telah dikumpulkan kemudian dipublikasi oleh guru kelas dengan mempostingnya di media sosial seperti whatsapp atau instagram. Media yang dipublikasi berupa gambar atau video yang menunjukan siswa beserta hasil kerja tugasnya. Berikut beberapa contoh screenshot hasil publikasi tugas para peserta didik yang dilakukan oleh guru kelas KB TK AlHuda.

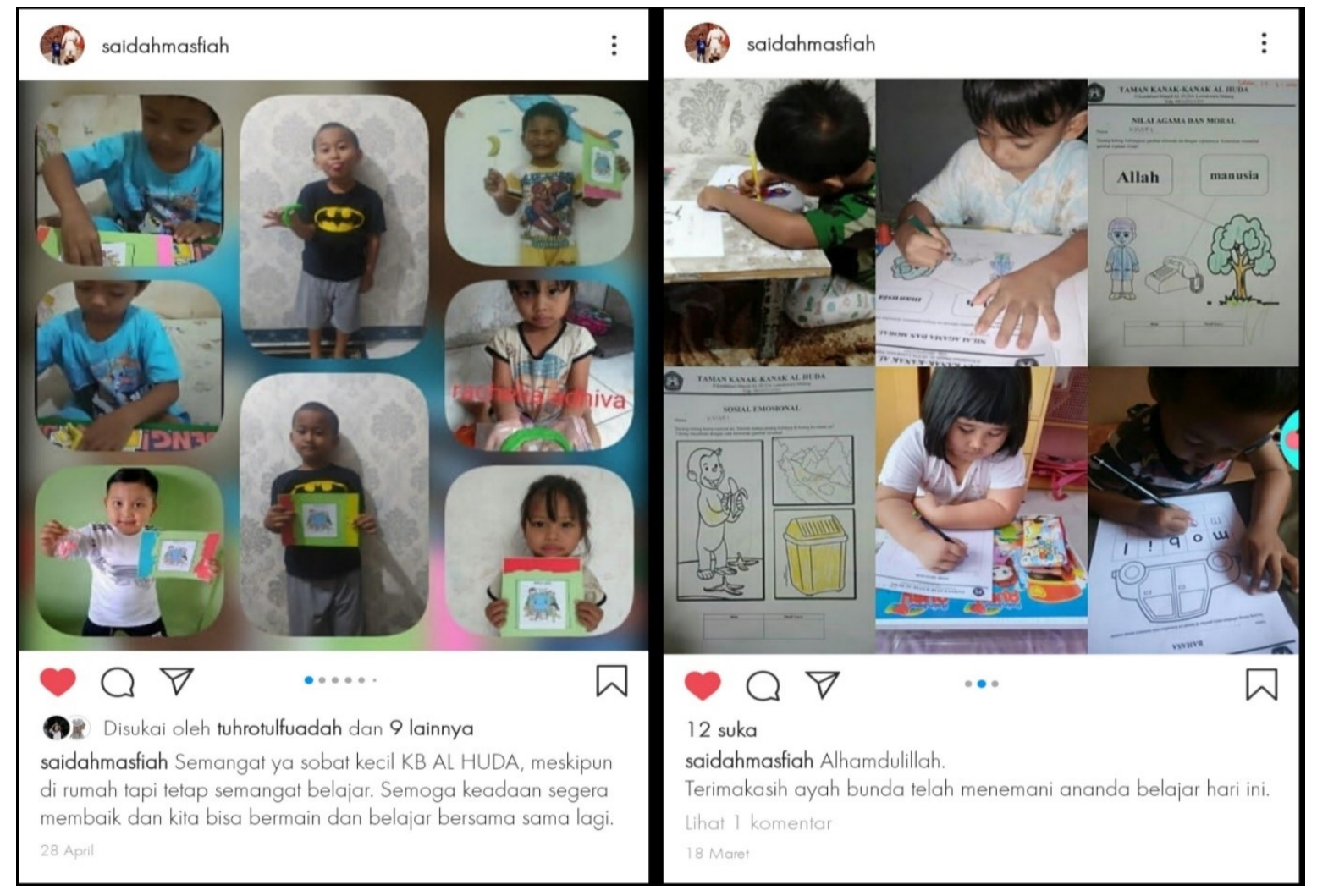

Gambar2. Contoh Postingan Guru Kelas di Instagram 
Gambar tersebut menunjukkan dimana guru tidak hanya sekedar mem-posting gambar siswa beserta hasil kerjanya, namun juga memberikan caption yang membangun semangat peserta didik. Misal, ungkapan pujian atas hasil kerja yang telah dikerjakan oleh anak serta semangatnya. Dengan begitu anak menjadi lebih merasa terapresiasi dan bersemangat dalam mengerjakan tugas-tugasnya. Kemudian, guru juga memberikan ucapan terima kasih kepada orangtua yang telah meluangkan waktunya mendampingi peserta didik dalam menyelesaikan tugasnya. Sehingga, orangtua juga merasa termotivasi untuk bersemangat dalam mendampingi anaknya belajar di rumah. Selain itu, tak lupa guru juga menyampaikan harapannya sebagai bentuk doa agar keadaan lekas membaik, sehingga anak-anak dapat belajar dan bermain bersama kembali di sekolah.

Guru kelas KB TK Al-Huda menjelaskan bahwa penerapan cara tersebut menunjukkan dampak positif dimana anak semakin bersemangat dalam mengerjakan tugasnya. Anak berlomba-lomba untuk segera mengerjakan dan mengirimkan tugas kepada guru kelas. Terkadang mungkin dalam suatu kondisi dimana orangtua masih sibuk atau lupa mengajak anak untuk mengerjakan tugas, sehingga anak belum mengerjakan tugas. Atau mungkin di rumah tidak ada gadget untuk mengirim tugas karena masih dibawa Ayah bekerja, sehingga anak belum mengirimkan tugas. Ketika melihat status whatsapp guru kelas yang berisi beberapa hasil kerja tugas teman-temannya yang lain, sementara ia belum mengerjakan, maka ia menjadi terpancing dan ingin segera mengerjakan tugasnya dan mengirimkannya kepada guru. Hal tersebut dapat memberi suatu dorongan sehingga anak tergerak untuk segera mengerjakan tugasnya, sebab melihat teman-temannya yang lainnya telah mengirimkan tugas dan di-share oleh guru kelas. Tentu sang anak akan memiliki keinginan pula Ia beserta hasil kerjanya dipublikasikan oleh guru.

Usaha meningkatkan motivasi belajar siswa melalui publikasi hasil belajar siswa tersebut dapat pula menjadi suatu bentuk apresiasi atau penghargaan bagi peserta didik. Sebab, ketika anak melihat bahwa ia beserta hasil kerja tugasnya diposting oleh gurunya dan dapat dilihat oleh banyak orang menjadi sumber kepuasaan dan kebahagiaan tersendiri bagi anak. Meskipun tidak berwujud secara fisik, namun bagi peserta didik, penghargaan menjadi suatu kebanggan yang sangat luar biasa. Hal tersebut semacam reward tak berwujud dari guru kepada siswa. Pemberian reward dapat menjadi suatu rangsangan untuk meningkatkan motivasi belajar peserta didik, sehingga anak merasa bahwa yang telah dilakukannya tidak sia-sia karena telah dihargai (Hapsari \& Christiana, 2013:274-284). Dengan begitu motivasi belajar peserta didik dapat meningkat dengan dorongan berupa pemberian reward. Selain itu, adanya pemberian reward juga dapat meningkatkan kedisiplinan siswa, dengan pemberian pujian, penghormatan, pemberian hadiah, serta tanda penghargaan (Ikranagara, 2015). Dalam hal kedisiplinan tersebut, jika dilihat pada pelaksanaan SFH di KB TK Al-Huda, para peserta didik yang berlomba-lomba untuk mengumpulkan tugas sebab termotivasi oleh hasil kerja tugas yang dipublikasi, menunjukkan adanya dorongan kedisiplinan para peserta didik, sehingga pengumpulan tugas tidak mengalami keterlambatan yang berlebih.

Upaya yang dipaparkan di atas dilakukan, sebab motivasi belajar merupakan hal yang sangat penting dalam suatu proses pembelajaran. Sebab, hasil belajar siswa akan sangat dipengaruhi oleh hal tersebut. Hasil belajar peserta didik dapat ditingkatkan dengan salah satu cara yaitu meningkatkan motivasi serta minat siswa yang dapat dicapai dengan meningkatkan kualitas guru dalam hal karakter pribadi maupun cara mengajarnya (Ricardo \& Meilani, 2017:188-201). Selain itu, hasil belajar yang diperolah siswa akan tercapai secara optimal bila ada motivasi belajar yang sangat menentukan intensitas dari usaha belajar siswa, dapat mendorong siswa untuk melakukan sesuatu, menentukan kemana arah yang siswa lakukan, menyeleksi apa yang siswa lakukan, serta mendorong siswa dalam berusaha mencapai prestasi, dimana disinilah guru berperan sebagai motivator siswa (Manizar, 2015:204-222). Pemaparan tersebut menunjukkan betapa berpengaruhnya guru dalam meningkatkan motivas belajar siswa. Sehingga, menjadi suatu keharusan bagi para guru 
untuk mencari cara sebagai upaya untuk meningkatkan motivasi belajar siswa, agar hasil belajar yang diperoleh dapat maksimal, terutama dalam kondisi di tengah wabah COVID-19 seperti ini.

\section{Hambatan Dalam Upaya Guru Meningkatkan Motivasi Belajar}

Menurut keterangan guru kelas KB TK Al Huda Kota Malang, dalam pelaksanaan upaya menumbuhkan motivasi belajar siswa melalui metode publikasi hasil kerja tugas tersebut ditemukan beberapa hambatan yang berkenaan dengan faktor orangtua peserta didik yang kurang kontributif dalam mendukung SFH ini. Kemudian, sarana pembelajaran juga menjadi hambatan berupa kebutuhan keterpenuhan sarana berupa gadget serta pendukungnya. Selain itu, kreativitas guru juga menjadi hambatan karena kurang dapat berkembang sebab kondisi yang menyulitkan serta memberikan tekanan. Meski ditemukan beberapa hambatan, namun guru kelas mengungkapkan bahwa secara umum pembelajaran dapat berjalan dengan baik. Berikut pembahasan lebih lengkapnya mengenai beberapa hambatan yang dihadapi oleh guru kelas tersebut.

Faktor penghambat pertama berhubungan dengan orangtua peserta didik. Orangtua merupakan salah satu faktor dari luar diri anak yang dapat mempengaruhi minat belajar, dimana dukungan dari orangtua dapat berupa dukungan emosional (kepedulian, perhatian, motivasi), dukungan penghargaan (dorongan positif atau pemberian reward), dukungan instrumental (biaya dan fasilitas belajar), serta dukungan informasi (petunjuk, saran, nasehat) (Diniaty, 2017:90-100). Selain itu, perhatian yang diberikan oleh orangtua kepada anak dapat meningkatkan motivasi belajar anak dalam mengerjakan tugas-tugas sekolah (Febriany \& Yusri, 2013:8-16). Apalagi bila dalam kebijakan SFH ini pembelajaran diganti dengan penugasan di rumah. Orangtua pada masa wabah COVID-19 ini memiliki pengaruh dominan terhadap anak dalam menjalankan peran yang selama ini dilaksanakan di satuan pendidikan, sebab distorsi dalam hal penjadualan waktu pembelajaran peserta didik, entah secara struktur, pembagian tugas, maupun internalisasi beberapa norma (Subarto, 2020:1318). Pemaparan tersebut menunjukan bagaimana urgensi peran orangtua dalam pelaksanaan SFH di tengah adanya wabah COVID-19 ini yang mengharuskan setiap orang untuk di melakukan semua kegiatannya di rumah saja, termasuk kewajiban belajar bagi para peserta didik yang sedang menempuh pendidikan.

Sayangnya, di KB TK Al-Huda, peran orangtua yang sangat urgen ini menjadi salah satu penghambat dalam pelaksanaan upaya peningkatan motivasi belajar peserta didik melalui publikasi. Guru kelas menjelaskan bahwa dalam hal penugasan, meski tidak semua orangtua, namun ada beberapa yang tidak dapat memahami perintah pengerjaan tugas dengan tepat, sehingga menimbulkan kesalahpahaman dalam pengerjaan tugas anak. Selain itu, permasalahan ini juga berkaitan dengan karakteristik orangtua yang kurang dapat bekerjasama dalam mensukseskan kegiatan belajar di rumah. Misalnya, orangtua yang tidak bersemangat atau telaten dalam membimbing anaknya untuk mengerjakan tugas serta melakukan pengumpulan tugas. Padahal, anak di usia dini apalagi yang masih Kelompok Bermain (KB) masih sangat membutuhkan bimbingan dari orang yang lebih tua. Terkadang, ada anak yang memiliki semangat tinggi, namun orangtuanya yang malas, begitupun sebaliknya. Sehingga untuk mensukseskan SFH ini perlu keseimbangan semangat yang tinggi antara orangtua dan anak. Namun, jikalau pun anak dalam keadaan malas, namun orangtua tetap bersemangat untuk berusaha memotivasi anak, maka pelan-pelan anak pun akan tumbuh motivasi belajarnya. Jadi disini peran orangtua sangatlah berpengaruh terhadap semangat belajar anak.

Faktor berikutnya yang dapat menghambat upaya guru dalam menghidupkan motivasi belajar siswa berkenaan dengan sarana pembelajaran. Dalam pelaksanaan SFH ini tentu sarana yang paling dibutuhkan adalah ketersediaan gadget sebagai penghubung dalam proses pembelajaran jarak jauh antara guru dan para peserta didik. Sarana pembelajaran yang dibutuhkan berupa gadget merupakan salah satu hambatan yang ditemukan dalam 
pelaksanaan SFH ini, dimana pada kenyataannya tidak semua peserta didik memiliki gadget, serta tidak semua pendidik ataupun peserta didik dan orangtua dapat menggunakan gadget dengan baik (Nasution, 2020). Padahal, terpenuhinya sarana pembelajaran merupakan suatu kemutlakan yang harus tersedia. Jika tidak, maka tentu saja akan menghambat jalannya pembelajaran. Sarana dan prasarana pembelajaran memiliki pengaruh yang besar terhadap motivasi belajar peserta didik, dimana bila pemenuhan sarana prasarana meningkat, maka akan diikuti pula meningkatnya motivasi belajar siswa (Putra \& Afriansyah, 2019).

Fakta yang ada di KB TK Al-Huda Kota Malang menunjukkan bahwa hambatan yang berhubungan dengan sarana pembelajaran berupa gadget tersebut juga ditemukan. Menurut keterangan dari guru kelas, ada peserta didik yang keluarganya di rumah yang memiliki gadget hanya ayahnya. Sehingga untuk mengumpulkan tugas, harus menunggu ayahnya pulang dari bekerja, sementara sang ayah kerja dari pagi hingga sore. Jadi, anak baru dapat mengerjakan atau mengumpulkan tugas saat malam hari. Berhubungan dengan sarana pembelajaran berupa gadget ini, tentu tidak lepas dari kebutuhan kuota internet pula. Harga kuota internet yang mungkin bagi sebagian orang tidak murah, tentu menjadi beban dan hambatan tersendiri. Apalagi didorong dengan keadaan di tengah wabah saat ini yang memberikan dampak bagi ekonomi masyarakat. Hal tersebut tentu akan menjadi hambatan dalam pelaksanaan proses pembelajaran.

Hambatan lain dalam upaya menghidupkan motivasi belajar peserta didik ini berhubungan dengan kreativitas guru. Kreativitas yang dimiliki guru berhubungan atau memiliki pengaruh terhadap hasil belajar peserta didik (Herawati, dkk., 2019:235-246). Kreativitas guru merupakan salah satu yang dapat mendorong motivasi belajar siswa, sebab guru yang kreatif dapat untuk mengembangkan kemampuannya, menciptakan ide-ide baru dalam menjalankan perannya sebagai pengajar (Oktiani, 2017:216-217). Jadi, kreativitas guru tidak hanya berpengaruh terhadap motivasi belajar siswa, namun secara langsung dapat berpengaruh terhadap hasil belajar siswa. Kreativitas yang dimiliki guru tentu harus ditumbuhkan serta dikembangkan dengan tidak hanya membutuhkan usaha pribadi guru tersebut, namun juga dukungan dari pihak-pihak di luar guru seperti kepala sekolah. Upaya pengembangan kreativitas tersebut dapat berupa pembinaan, pelatihan, supervisi, maupun dorongan dari luar barupa pemberian penghargaan dari atasan.

Pemaparan di atas menunjukkan bahwa kreativitas memang sangat penting dimiliki oleh seorang guru. Dalam penerapan SFH di Kelompok Bermain (KB) TK Al-Huda, dalam kegiatan wawancara guru kelas menjelaskan bahwa beliau memiliki hambatan dalam hal kreativitas. Dalam kondisi yang serba terbatas, serta belum pernah kondisi seperti ini dialami sebelumnya, menuntut guru berpikir keras untuk tetap menjalankan pembelajaran dengan baik. Dalam sistem pembelajaran di rumah berupa pemberian tugas, guru dituntut harus banyak menemukan ide-ide bentuk tugas yang sesuai dengan kondisi orangtua maupun peserta didik di rumah. Selain itu juga harus sesuai dengan segala keterbatasan kondisi yang ada. Guru juga harus memikirkan tugas-tugas yang bervariasi agar peserta didik tidak merasa bosan karena mengerjakan jenis tugas yang sejenis secara berulangkali. Sehingga rawan terhadap krisis ide yang dapat menimpa guru. Selain itu, kondisi pembelajaran yang dilakukan di rumah tentu akan berbeda dengan dilaksanakan di sekolah. Di sekolah guru lebih akan berkembang kreativitasnya sebab segala perlengkapan pembelajaran di sekolah tersedia sehingga guru tidak akan kesulitan memunculkan ide-ide tugas yang bervariasi. Namun, kondisi terbatas seperti yang terjadi saat adanya wabah COVID-19 ini yang menuntut harus di rumah saja, tentu menekan kreativitas guru sehingga sulit untuk berkembang.

\section{Manfaat Penerapan Publikasi Hasil Kerja Tugas dalam Upaya Meningkatkan Motivasi Belajar Siswa}

Sebagaimana dipaparkan sebelumnya di atas bahwa bentuk usaha guru kelas Kelompok Bermain (KB) TK Al-Huda Kota Malang dalam menghidupkan motivasi belajar 
siswa adalah dengan publikasi hasil kerja tugas siswa di rumah. Tindakan tersebut ternyata memberikan hasil berupa manfaat tidak hanya bagi peserta didik, namun juga orangtua. Menurut keterangan guru kelas, dengan penerapan publikasi hasil kerja tugas yang dilakukan oleh guru kelas Kelompok Bermain (KB) TK Al-Huda, motivasi belajar para peserta didik hidup. Meski sistem pembelajaran berubah, dimana anak-anak tidak belajar dengan guru dan teman-teman kelasnya, namun anak tetap memiliki semangat untuk belajar di rumah meski sesekali mengeluh rindu untuk bertemu guru dan teman-temannya. Anak yang melihat hasil kerjanya di-share oleh guru menjadi bersemangat untuk mengerjakan dan menyelesaikan setiap tugasnya.

Manfaat selanjutnya adalah strategi ini dapat membantu dalam melatih kedisiplinan peserta didik. Dari penerapan publikasi hasil kerja tugas yang dilakukan oleh guru kelas Kelompok Bermain (KB) TK Al-Huda, beliau menjelaskan bahwa anak menjadi disiplin dalam mengumpulkan tugas sesuai jadwal hari yang telah ditentukan oleh guru. Sebab, ketika siswa belum mengerjakan dan mengirimkan tugas kepada guru, kemudian melihat teman-teman yang lain hasil kerja tugasnya telah di-posting oleh guru, tentu ia juga menginginkan hal tersebut. Sehingga anak menjadi disiplin dalam mengumpulkan tugas. Kedisiplinan merupakan hal yang sangat penting. Kedisiplinan merupakan hal yang harus diajarkan sejak usia dini yang merupakan kewajiban guru untuk membimbing anak didiknya, agar anak dapat menerapkannya hingga jenjang lebih lanjut (Yahdillah, 2019).

Selanjutnya, manfaat lain dari penerapan metode ini adalah dapat membantu meningkatkan kedekatan antara orangtua dan anak. Sebagaimana dipaparkan di atas sebelumnya, bahwa bentuk SFH di Kelompok Bermain (KB) TK Al-Huda berupa penugasan yang dikerjakan oleh anak di rumah. Dalam pengerjaan tugas ini tentu anak tidak mengerjakan sendiri, melainkan perlu pendampingan serta bimbingan dari orangtua. Ketika orangtua menemani serta membimbing anak dalam menyelesaikan tugasnya, tentu banyak terjadi interaksi antara keduanya. Orangtua menjadi semakin memiliki banyak waktu bersama anak dan secara tidak langsung dapat lebih memahami anaknya. Disinilah momen kedekatan antara orangtua dan anak tercipta dan terpupuk.

\section{SIMPULAN}

Berdasarkan hasil penelitian ini dapat disimpulkan bahwa bentuk strategi guru untuk menghidupkan motivasi belajar siswa dalam kebijakan SFH di tengah wabah COVID19 dengan publikasi hasil kerja tugas siswa terbukti dapat memotivasi siswa untuk melaksanakan SFH. Beberapa hambatan yang ditemui guru dalam pelaksanaan metode publikasi tersebut berhubungan dengan aspek orangtua peserta didik, sarana pembelajaran, dan kreativitas guru. Adanya penerapan publikasi hasil kerja tugas siswa tersebut memberikan manfaat berupa tumbuhnya motivasi belajar siswa, melatih kedisiplinan siswa, serta membantu meningkatkan kedekatan antara orangtua dan anak. Meski cara ini terbilang sederhana, namun hasil penelitian ini menunjukkan bahwa cara ini cukup efektif dalam menumbuhkan motivasi belajar siswa. Dalam penerapannya pun dibutuhkan kekonsistenan guru dalam melaksanakannya, agar hasil yang diperoleh dapat maksimal. Selain itu, kerja sama dari orangtua juga dibutuhkan agar pelaksanaan SFH dapat berjalan secara optimal sebagaimana yang diharapkan.

\section{UCAPAN TERIMAKASIH}

Terima kasih yang sebesar-besarnya peneliti sampaikan kepada Lembaga PAUD TK Al-Huda Kota Malang, khusunya kelas Kelompok Bermain (KB) sebagai objek dalam penelitian ini. Rasa terima kasih yang sedalam-dalamnya juga peneliti persembahkan kepada Ibu Saidah Masfiah, selaku Kepala Sekolah dan guru kelas Kelompok Bermain (KB) TK Al-Huda yang telah bersedia menjadi subjek penelitian dan meluangkan waktunya untuk diwawancarai sebagai langkah pengumpulan data. Penelitian ini tentu tidak akan terlaksana dengan baik jika tanpa bantuan beliau. Sekali lagi peneliti ucapkan terima kasih 
yang sebesar-besarnya kepada semua pihak yang telah berpartisipasi demi berjalannya penelitian ini yang mungkin belum disebutkan.

\section{DAFTAR PUSTAKA}

Aulina, C. N. (2018). Penerapan Metode Whole Brain Teaching dalam Meningkatkan Motivasi Belajar Anak Usia Dini. Jurnal Obsesi : Jurnal Pendidikan Anak Usia Dini, 2(1), 1. https:// doi.org/10.31004/obsesi.v2i1.1

Damanik, B. E. (2019). Pengaruh Fasilitas Dan Lingkungan Belajar Terhadap Motivasi Belajar. Publikasi Pendidikan, 9(1), 46. https://doi.org/10.26858/publikan.v9i1.7739

Diniaty, A. (2017). Dukungan Orangtua terhadap Minat Belajar Siswa. Jurnal Al-Taujih: Bingkai Bimbingan dan Konseling Islami, 3(1), 90-100. Diambil dari https://ejournal.uinib.ac.id/jurnal/index.php/attaujih/article/view/592

Emda, A. (2018). Kedudukan Motivasi Belajar Siswa Dalam Pembelajaran. Lantanida Journal, 5(2), 172. https:// doi.org/10.22373/lj.v5i2.2838

Fathurrahman. (2020). Penggunaan Metode Pembelajaran Role Playing Dalam Menumbuhkan Motivasi Belajar Pada Pembelajaran Sejarah [Preprint]. https://doi.org/10.35542/osf.io/stnwa

Febriany, R., \& Yusri, Y. (2013). Hubungan Perhatian Orangtua Dengan Motivasi Belajar Siswa Dalam Mengerjakan Tugas-Tugas Sekolah. Konselor, 2(1). https://doi.org/10.24036/0201321727-0-00

Firman, F., \& Rahayu, S. (2020). Pembelajaran Online di Tengah Pandemi Covid-19. Indonesian Journal of Educational Science (IJES), 2(2), 81-89. https://doi.org/10.31605/ijes.v2i2.659

Halodoc. (2020, Maret 2). Begini Kronologi Lengkap Virus Corona Masuk Indonesia. Diambil dari https://www.halodoc.com/kronologi-lengkap-virus-corona-masuk-indonesia

Hapsari, R. P., \& Christiana, E. (2013). Studi Tentang Pelaksanaan Pemberian Reward Dalam Meningkatkan Motivasi Belajar Kelompok-A Di TK Islam Al-Azhar 35 Surabaya. Jurnal Mahasiswa Bimbingan Konseling UNESA, 4(1), 274-284. Diambil dari http://jurnalmahasiswa.unesa.ac.id/index.php/jurnal-bk-unesa/article/view/ 6591

Hasanah, U. (2015). Hubungan Lingkungan Sekolah dan Motivasi Belajar Dengan Hasil Belajar IPS Siswa Kelas VIII Di MtsN Amuntai. Jurnal Socius, 4(2). https://doi.org/10.20527/jurnalsocius.v4i2.3314

Herawati, R., Mujahidin, E., \& Hamat, A. A. (2019). Hubungan Motivasi Dan Kreativitas Guru Dalam Mengajar Dengan Hasil Belajar Mata Pelajaran PAI Di Madrasah Aliyah

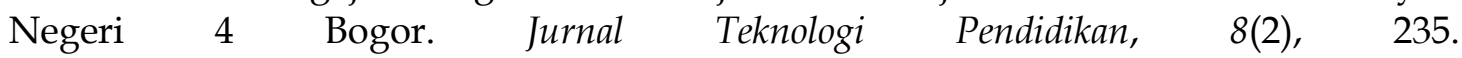
https://doi.org/10.32832/tek.pend.v8i2.1507

Ibrahim, A. M. (2020, April 26). Dampak Covid-19 Terhadap Perekonomian dan Kebijakan Pemerintah Indonesia. Diambil 2 Juni 2020, dari Https://sukabumiupdate.com/ website: https://sukabumiupdate.com/detail/bale-warga/opini/68505-DampakCovid-19-Terhadap-Perekonomian-dan-Kebijakan-Pemerintah-Indonesia

Ikranagara, P. (2015). Pemberian Reward Dan Punishment Untuk Meningkatkan Kedisiplinan Siswa Dalam Pembelajaran IPS Kelas V SD Negeri 1 Kejobong Purbalingga. BASIC EDUCATION, 4(2). Diambil dari http://eprints.uny.ac.id/id/eprint/13568

Jamaluddin, D., Ratnasih, T., Gunawan, H., \& Paujiah, E. (2020). Pembelajaran Daring Masa Pandemik Covid-19 Pada Calon Guru: Hambatan, Solusi Dan Proyeksi. 1-10. Diambil dari http://digilib.uinsgd.ac.id/id/eprint/30518

Manizar, E. (2015). Peran Guru Sebagai Motivator Dalam Belajar. 1(2), 204-222. Diambil dari http://jurnal.radenfatah.ac.id/index.php/Tadrib/article/view/1047

Nasution, M. R. (2020). Covid-19 Tidak Menjadi Hambatan Pendidikan Di Indonesia? https://doi.org/10.13140/RG.2.2.28543.36005/1 
Oktiani, I. (2017). Kreativitas Guru dalam Meningkatkan Motivasi Belajar Peserta Didik. Jurnal Kependidikan, 5(2), 216-232. https:// doi.org/10.24090/jk.v5i2.1939

Peraturan Menteri Kesehatan Republik Indonesia Nomor 9 Tahun 2020 tentang Pedoman Pembatasan Sosial Berskala Besar dalam Rangka Percepatan Penanganan Corona Virus Disease 2019. , Pub. L. No. Berita Negara Republik Indonesia Tahun 2020 Nomor 326 (2020).

Peraturan Menteri Pendidikan Dan Kebudayaan Republik Indonesia Nomor 146 Tahun 2014 tentang Kurikulum 2013 Pendidikan Anak Usia Dini. , Pub. L. No. Berita Negara Republik Indonesia Tahun 2014 Nomor 1679 (2014).

Peraturan Menteri Pendidikan Dan Kebudayaan Republik Indonesia (RI) Nomor 137 Tahun 2014 tentang Standar Nasional Pendidikan Anak Usia Dini. , Pub. L. No. Berita Negara Republik Indonesia Tahun 2014 Nomor 1668 (2014).

Putra, A. D., \& Afriansyah, H. (2019). Pentingnya Sarana dan Prasarana Pembelajaran terhadap Motivasi Belajar Siswa SMAN 16 Tebo [Preprint]. https:// doi.org/10.31227/osf.io/yt4b7

Ricardo, R., \& Meilani, R. I. (2017). Impak Minat dan Motivasi Belajar Terhadap Hasil Belajar $\begin{array}{llll}\text { Siswa. Jurnal Pendidikan Manajemen } & 79 .\end{array}$ https:// doi.org/10.17509/jpm.v2i2.8108

Siregar, H. I. (2015). Peningkatkan Motivasi Belajar Siswa Dalam Pembelajaran Microsoft Excel Dengan Menggunakan Metode Tutor Sebaya Di Kelas VIII-D SMP Negeri 1 Batangkuis. SCHOOL EDUCATION JOURNAL PGSD FIP UNIMED, 4(1), 127-140. https:// doi.org/10.24114/sejpgsd.v4i1.2982

Subarto. (2020). Momentum Keluarga Mengembangkan Kemampuan Belajar Peserta Didik Di Tengah Wabah Pandemi Covid-19. ADALAH, 4(1), 3-18. https:// doi.org/10.15408/adalah.v4i1.15383

Suryani, M. (2015). Meningkatkan Motivasi Belajar Pembelajaran Untuk Siswa Kelas V SD Negeri 04 Pasar Pandan Air (PPA) Mati Solok Melalui Metode Inquiry. Inovasi Pembelajaran Berbasis Riset di Sekolah Dasar, 1, 1. Diambil dari http://ejournal.unp.ac.id/index.php/prosidingpgsd/article/view/4872

Syah, R. H. (2020). Dampak Covid-19 pada Pendidikan di Indonesia: Sekolah, Keterampilan, dan Proses Pembelajaran. SALAM: Jurnal Sosial dan Budaya Syar-i, 7(5). https:// doi.org/10.15408/sjsbs.v7i5.15314

Undang-Undang Republik Indonesia Nomor 20 Tahun 2003 tentang Sistem Pendidikan Nasional. , Pub. L. No. Lembaran Negara Republik Indonesia Nomor 4301 (2003).

Yahdillah. (2019). Meningkatkan Kedisiplinan Siswa [Preprint]. https://doi.org/10.31227/osf.io/qxkgu 